\title{
Kemampuan Berpikir Refraktif Matematis Mahasiswa melalui Pembelajaran Peer-Assited Reflection
}

\author{
Isra Nurmai Yenti ${ }^{1,2 *}$, Yaya S. Kusumah ${ }^{2}$, Jarnawi Afghani Dahlan ${ }^{2}$ \\ ${ }^{1}$ Program Studi Pendidikan Matematika, Institut Agama Islam Negeri Batusangkar \\ ${ }^{2}$ Program Studi Pendidikan Matematika, Universitas Pendidikan Indonesia \\ *isranurmaiyenti@iainbatusangkar.ac.id
}

\begin{abstract}
Abstrak
Berpikir refraktif perlu dikembangkan dalam perkuliahan karena memiliki peran penting dalam pengambilan keputusan. Namun, sejauh ini, belum ditemukan penelitian relevan yang mengembangkan berpikir refraktif melalui penerapan suatu strategi pembelajaran. Penelitian ini bertujuan untuk memperoleh gambaran peningkatan kemampuan berpikir refraktif matematis melalui penerapan pembelajaran Peer-Assisted Reflection dan pengaruh interaksi faktor pembelajaran dan level kemampuan awal matematis pada peningkatan kemampuan berpikir refraktif matematis. Penelitian ini merupakan penelitian kuantitatif dengan desain eksperimen semu. Dengan teknik purposive sampling, terpilih 73 orang mahasiswa yang mengambil mata kuliah Kalkulus Multivariabel. Instrumen yang digunakan adalah tes kemampuan awal matematis dan tes kemampuan berpikir refraktif matematis. Analisis data memakai uji- $t$, uji- $t$, uji Mann-Whitney U, Aligned Rank Transform, dan ANOVA dua arah. Temuan dari penelitian ini adalah: (1) Peningkatan kemampuan berpikir refraktif matematis mahasiswa yang memperoleh pembelajaran Peer-Assisted Reflection lebih baik daripada yang memperoleh pembelajaran konvensional untuk semua level kemampuan awal matematis, (2) Tidak terdapat pengaruh yang signifikan pada interaksi antara pembelajaran dan kemampuan awal matematis terhadap peningkatan kemampuan berpikir refraktif matematis.
\end{abstract}

Kata kunci: kemampuan awal matematis, kemampuan berpikir refraktif matematis, pembelajaran Peer-Assisted Reflection

\begin{abstract}
Refractive thinking needs to be developed in lectures because it has an essential role in decision-making. However, so far, there has not been found any relevant research that develops refractive thinking through applying a learning strategy. The purpose of this study was to obtain an overview of the enhancement of students' mathematical refractive thinking ability based on prior mathematical knowledge through the application of PeerAssisted Reflection learning and the influence of the interaction of learning factors and the level of prior mathematical knowledge on enhancing mathematical refractive thinking ability. This research is a quantitative study with a quasi-experimental design. Using the purposive sampling technique, 73 students were selected to take the Multivariable Calculus course. The research sample was students who took the Multivariable Calculus course. The instrument used was a prior mathematical knowledge test and a mathematical refractive thinking ability test. Data analysis used $t$ test, $t^{\prime}$-test, Mann-Whitney U test, Aligned Rank Transform, and two-way ANOVA. The findings of this study are: (1) The enhancement of students' mathematical refractive thinking ability who got Peer-Assisted Reflection learning is better than those who got conventional learning for all levels of prior mathematical knowledge; and (2) There is no significant effect on the interaction between learning and prior mathematical knowledge on improving mathematical refractive thinking ability.

Keywords: prior mathematical knowledge, mathematical refractive thinking ability, Peer-Assisted Reflection learning
\end{abstract}




\section{Pendahuluan}

Mahasiswa membutuhkan berpikir refraktif dalam menyelesaikan masalah matematis. Berpikir refraktif terjadi pada saat mahasiswa membuat keputusan dalam menentukan penyelesaian (proses maupun hasil) masalah matematis (Prayitno, Subanji, \& Muksar, 2016). Mereka membuat keputusan terhadap masalah open-ended yang telah diberikan. Dengan demikian, berpikir refraktif memiliki peran penting dalam pengambilan keputusan sehingga perlu dikembangkan dalam perkuliahan.

Peneliti menelusuri berpikir refraktif yang dimiliki mahasiswa melalui pemberian sebuah masalah tentang materi koordinat Cartesius di ruang-tiga (Gambar 1). Sekitar 93\% mahasiswa yang mengerjakan masalah tersebut, tidak mampu mengidentifikasi masalah dengan benar. Akibatnya, sebagian besar dari mereka tidak bisa menentukan konsep dan tidak menemukan strategi penyelesaian. Pada akhirnya, tidak ada satupun mahasiswa yang dapat menyelesaikan masalah yang diberikan. Dari studi awal tersebut, dapat disimpulkan bahwa berpikir refraktif matematis mahasiswa masih lemah.

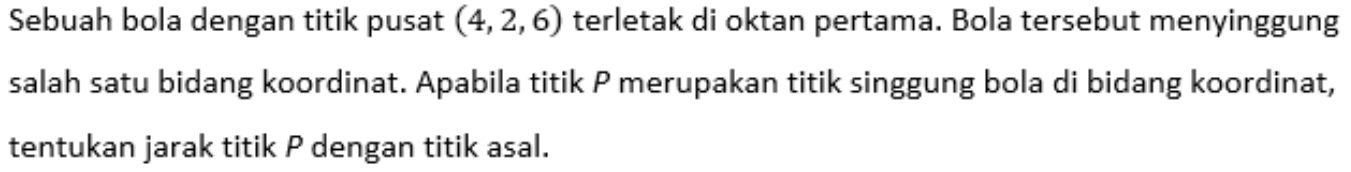

Gambar1. Masalah untuk Studi Awal Berpikir Refraktif Matematis

Berdasarkan studi literatur, belum ditemukan penelitian yang mengembangkan berpikir refraktif dalam pembelajaran melalui penerapan suatu model/strategi. Penelitian terdahulu hanya mengungkapkan proses berpikir refraktif (Prayitno, Subanji, \& Muksar, 2016), berpikir refraktif pada tipe kepribadian Keirsey (Prihati \& Wijayanti, 2017), berpikir refraktif berdasarkan kemampuan matematis (Maslukha, Lukito, \& Ekawati, 2018), dan berpikir refraktif ditinjau dari gaya belajar (Fatmalasari \& Siswono, 2020). Dengan demikian, peneliti tertarik meningkatkan berpikir refraktif matematis melalui penerapan suatu strategi pembelajaran.

Dalam penelitian ini, berpikir refraktif matematis mahasiswa diukur melalui kemampuan berpikir. Kemampuan berpikir refraktif matematis (KBRM) terdiri atas 3 komponen, yaitu mengidentifikasi masalah, menyusun strategi dan melakukan evaluasi (Prayitno, Sutawidjaja, Subanji \& Muksar, 2014; Prihati \& Wijayanti, 2017; Fatmalasari \& Siswono, 2020). Komponen mengidentifikasi masalah dijabarkan ke dalam 3 indikator, yaitu: (1) menuliskan kembali informasi yang diberikan soal, (2) menafsirkan situasi matematis secara rasional, dan (3) merepresentasikan ide dalam bentuk simbol matematis, gambar atau tabel. Komponen 
menyusun strategi diuraikan dalam 3 indikator, yakni: (1) mengidentifikasi hubungan antara pernyataan, pertanyaan dan konsep matematis, (2) mengajukan beberapa kemungkinan alternatif solusi dalam pemecahan masalah matematis, dan (3) memilih alternatif solusi yang paling relevan dan digunakan untuk menyelesaikan masalah matematis. Komponen melakukan evaluasi dijabarkan ke dalam 2 indikator, yaitu mengevaluasi alternatif penyelesaian maupun jawaban yang dihasilkan dengan mempertimbangkan informasi yang relevan dan menjelaskan kembali informasi yang dihasilkan.

Pembelajaran Peer-Assisted Reflection (PAR) diduga dapat mengembangkan KBRM. Hal ini didasari oleh masalah yang digunakan dalam pembelajaran PAR adalah masalah openended (Reinholz \& Dounas-Frazer, 2016). Schoenfeld (dalam Reinholz, 2016) menyatakan bahwa tugas open ended dengan banyak solusi mendukung pembelajaran melalui analisis. Pada saat menyelesaikan masalah open-ended tersebut, mereka melakukan kegiatan identifikasi masalah, menyusun strategi dan mengevaluasi. Ketiga kegiatan ini merupakan komponen dari KBRM.

Sadler (dalam Reinholz, 2015) mengungkapkan bahwa pembelajaran Peer-Assisted Reflection menggabungkan dua kegiatan yaitu peer analysis dan self-reflection. Aktivitas yang dilakukan mahasiswa dalam pembelajaran PAR adalah: (1) melengkapi masalah PAR secara individu di luar kelas, (2) self-reflect, (3) menukarkan hasil kerja dengan rekan sejawat dan memberikan umpan balik, dan (4) melakukan revisi di luar kelas untuk menghasilkan solusi akhir (Reinholz, 2015; Calkins, Grannan, \& Siefken, 2020). Pada penelitian ini, semua aktivitas pembelajaran PAR dilaksanakan dalam kelas untuk meminimalkan terjadinya kendala dalam memahami masalah open-ended.

Peningkatan KBRM yang diperoleh mahasiswa melalui pembelajaran PAR ditinjau dari segi kemampuan awal matematis (KAM). Maslukha, Lukito, \& Ekawati (2018) menyatakan bahwa cara berpikir refraktif dapat dipengaruhi oleh kemampuan awal dan pengalaman belajar sebelumnya. Oleh sebab itu, penelitian ini bertujuan untuk mendeskripsikan: 1) Peningkatan KBRM mahasiswa berdasarkan KAM setelah penerapan pembelajaran PAR; dan 2) Pengaruh interaksi antara pembelajaran PAR dan KAM terhadap peningkatan KBRM.

\section{Metode}

Penelitian ini menggunakan desain eksperimen semu dengan jenis nonequivalent pretest and posttest control-group design. Hal ini disebabkan oleh penempatan mahasiswa pada kedua kelompok penelitian tidak secara acak, akan tetapi mengikuti kelas yang sudah ada. Seluruh 
mahasiswa pendidikan matematika pada suatu Perguruan Tinggi Agama Islam Negeri di Sumatera Barat menjadi populasi dalam penelitian ini. Mahasiswa yang mengambil mata kuliah Kalkulus Multivariabel sebanyak 73 orang dipilih sebagai sampel penelitian dengan teknik purposive sampling. Pengumpulan data dilakukan dengan menggunakan tes yang terdiri atas tes KAM dan tes KBRM.

Peneliti merancang tes KAM yang berisi soal-soal dari materi prasyarat yang diujikan pada tes KBRM. Materi tes KAM berkaitan dengan grafik persamaan linier, koordinat polar, lingkaran dan konik, dan turunan fungsi satu peubah beserta penerapannya. Materi yang diujikan pada tes KBRM berkaitan dengan koordinat Cartesius di ruang-tiga, permukaan di ruang-tiga, koordinat silinder, koordinat sferis, turunan fungsi dua peubah serta penerapannya. Tes KAM terdiri atas 6 soal uraian, sedangkan tes KBRM terdiri atas 4 soal uraian. Contoh soal yang diujikan pada tes KAM dan tes KBRM disajikan dalam Gambar 2 berikut.

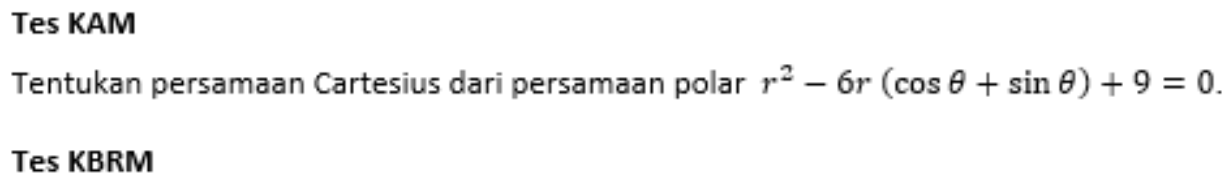
bidang-xy sebagai alasnya. la hanya diberitahu oleh pengurus mesjid bahwa kubah mesjid tersebut memiliki diameter alas $6 \mathrm{~m}$ dan tinggi kubah $4 \mathrm{~m}$. Berikut ini diberikan beberapa persamaan sebagai alternatif yang dapat membantu arsitek untuk membuat gambar kubah mesjid.

$$
z=\sqrt{16-\frac{16}{9} x^{2}-\frac{16}{9} y^{2}} \quad \rho=3 \quad 16 r^{2}+9 z^{2}=144
$$

a. Apakah situasi matematis dari menggambar sketsa sebuah kubah mesjid sudah memadai? Jika sudah, identifikasi situasi atau persamaan matematis yang diberikan!

b. Jelaskan konsep-konsep yang dapat digunakan untuk menyelesaikan masalah menggambar sketsa sebuah kubah mesjid tersebut!

c. Tuliskan beberapa alternatif cara yang dapat dilakukan untuk menyelesaikan masalah menggambar sketsa sebuah kubah mesjid di atas! Berikan alasan terhadap alternatif mana yang kamu pilih dan selesaikan permasalahannya berdasarkan cara tersebut.

d. Periksa kembali hasil kerjamu dengan menggunakan informasi yang diberikan soal. Berikan penjelasan tentang langkah-langkah yang dilakukan.

\section{Gambar 2. Contoh Soal pada Tes KAM dan Tes KBRM}

Sebelum kedua instrumen tes diberikan kepada mahasiswa sampel penelitian, tes tersebut divalidasi oleh pakar dan diujicobakan secara terbatas. Hasil validitas isi dan validitas muka untuk tes KAM adalah valid, begitu juga untuk tes KBRM. Validitas butir untuk tes KAM adalah: 2 soal dengan kategori baik dan 4 soal dengan kategori cukup baik. Validitas butir untuk tes KBRM adalah: 3 soal dengan kategori baik dan 1 soal dengan kategori sangat buruk. Kedua tes memiliki reliabilitas cukup baik. Dengan demikian, kedua instrumen dapat digunakan dalam penelitian dengan mengganti soal yang validitas butirnya sangat buruk dengan soal sejenis. 
Rerata skor $(\bar{x})$ dan simpangan baku $(s)$ digunakan untuk mengelompokkan siswa berdasarkan KAM, seperti terlihat pada Tabel 1.

Tabel 1. Kategori jenis kemampuan matematis

\begin{tabular}{lccc}
\hline \multicolumn{1}{c}{ Skor KAM } & Skor KAM di PAR & Skor KAM di PK & Kategori \\
\hline \multicolumn{1}{c}{$\mathrm{KAM} \geq \bar{x}+s$} & $\mathrm{KAM} \geq 25,05$ & $\mathrm{KAM} \geq 22,42$ & Tinggi \\
\hline $\bar{x}-s \leq \mathrm{KAM}<\bar{x}+\mathrm{s}$ & $6,55 \leq \mathrm{KAM}<25,05$ & $6,26 \leq \mathrm{KAM}<22,42$ & Sedang \\
\hline \multicolumn{1}{c}{$\mathrm{KAM}<\bar{x}-\mathrm{s}$} & $\mathrm{KAM}<6,55$ & $\mathrm{KAM}<6,26$ & Rendah \\
\hline Keterangan: & & & \\
Skor ideal KAM $=100$ & & & \\
PK $=$ pembelajaran konvensional & & & \\
\hline
\end{tabular}

Untuk memperoleh data peningkatan KBRM dilakukan dengan menghitung normalized gain ( $N$ gain) pretes dan postes KBRM yang dikemukakan oleh Meltzer (2002). Interpretasi nilai $N$ gain mengacu pada pendapat Hake (1998). Selanjutnya data tersebut dianalisis menggunakan uji-t, uji-t', uji Mann-Whitney U, Aligned Rank Transform (ART) dan ANOVA dua arah.

\section{Hasil Penelitian}

Statistik deskriptif untuk data KBRM disajikan pada Tabel 2. Data peningkatan KBRM diperoleh dari skor $N$ gain KBRM.

Tabel 2. Statistik deskriptif data kemampuan berpikir refraktif matematis

\begin{tabular}{|c|c|c|c|c|c|c|c|c|c|}
\hline \multirow{2}{*}{$\mathbf{K A M}$} & \multirow{2}{*}{ Stat } & \multicolumn{4}{|c|}{ PAR } & \multicolumn{4}{|c|}{ PK } \\
\hline & & Pretes & Postes & $N$ gain & $n$ & Pretes & Postes & $N$ gain & $n$ \\
\hline \multirow{2}{*}{ Tinggi } & $\bar{x}$ & 7,75 & 23,83 & 0,31 & \multirow{2}{*}{6} & 4,93 & 8,29 & 0,06 & \multirow{2}{*}{7} \\
\hline & $S$ & 2,79 & 5,67 & 0,12 & & 1,72 & 6,49 & 0,12 & \\
\hline \multirow{2}{*}{ Sedang } & $\bar{x}$ & 6,50 & 14,56 & 0,15 & \multirow{2}{*}{27} & 4,19 & 6,40 & 0,04 & \multirow{2}{*}{26} \\
\hline & $S$ & 1,91 & 8,86 & 0,15 & & 2,35 & 3,91 & 0,07 & \\
\hline \multirow{2}{*}{ Rendah } & $\bar{x}$ & 3,25 & 10,00 & 0,12 & \multirow{2}{*}{2} & 4,80 & 4,30 & 0,00 & \multirow{2}{*}{5} \\
\hline & $S$ & 2,47 & 1,41 & 0,01 & & 3,44 & 0,76 & 0,07 & \\
\hline \multirow{2}{*}{ Total } & $\bar{x}$ & 6,53 & 15,89 & 0,18 & \multirow{2}{*}{35} & 4,41 & 6,47 & 0,04 & \multirow{2}{*}{38} \\
\hline & $S$ & 2,24 & 8,91 & 0,15 & & 2,36 & 4,30 & 0,08 & \\
\hline
\end{tabular}

Berdasarkan hasil di Tabel 2, secara umum mahasiswa yang mendapatkan pembelajaran PAR mengalami rerata peningkatan KBRM yang lebih tinggi dibandingkan mahasiswa yang mendapatkan pembelajaran konvensional. Rerata peningkatan KBRM mahasiswa pada kelompok pembelajaran PAR juga lebih besar dibandingkan mahasiswa pada kelompok pembelajaran konvensional jika dinyatakan dalam KAM (tinggi, sedang, dan rendah).

Rerata peningkatan KBRM mahasiswa kelompok pembelajaran PAR dan pembelajaran konvensional adalah 0,18 dan 0,04 . Berdasarkan kategori $N$ gain yang dikemukakan oleh Hake (1998), peningkatan KBRM pada kedua kelompok adalah rendah. Artinya, kontribusi 
pembelajaran PAR terhadap KBRM mahasiswa sangat sedikit, sedangkan pembelajaran konvensional tidak memberikan peningkatan terhadap KBRM mahasiswa.

Pada Tabel 2 juga terlihat peningkatan KBRM mahasiswa pada pembelajaran PAR untuk setiap kategori KAM. Pada pembelajaran konvensional, peningkatan KBRM hanya terjadi pada mahasiswa KAM tinggi dan sedang. Semakin tinggi kategori KAM mahasiswa, maka peningkatan KBRM juga semakin tinggi.

Di Tabel 2, KBRM mahasiswa KAM rendah pada pembelajaran konvensional tidak mengalami peningkatan. Jika ditinjau skor postes yang diperoleh mahasiswa KAM rendah, rerata hasil pretes lebih tinggi dibandingkan hasil postes, padahal mereka belum pernah sebelumnya belajar materi yang diteliti. Dengan kata lain, tidak terjadi perubahan pola pikir terutama pada berpikir refraktif matematis pada mahasiswa KAM rendah setelah dilakukan pembelajaran konvensional. Setelah ditelusuri skor yang diperoleh mahasiswa tiap indikator antara hasil postes dan pretes, mahasiswa KAM rendah pada pembelajaran konvensional hanya mampu mengidentifikasi masalah dan mereka melakukan kegiatan ini dengan baik pada saat mengerjakan postes.

\section{Peningkatan Kemampuan Berpikir Refraktif Matematis Mahasiswa Berdasarkan}

\section{Kemampuan Awal Matematis}

Dari pemaparan hasil yang disajikan pada Tabel 2, perlu dilakukan pengujian secara statistik inferensial, baik secara keseluruhan maupun berdasarkan KAM, terhadap perbedaan rerata peningkatan KBRM antara mahasiswa pembelajaran PAR dan pembelajaran konvensional. Sebelum pengujian perbedaan rerata, perlu diselidiki normalitas data. Uji Shapiro-Wilk paling direkomendasikan untuk uji normalitas data (Ghasemi \& Zahediasl, 2012). Khusus data peningkatan KBRM pada pembelajaran PAR untuk mahasiswa KAM rendah tidak diuji normalitasnya dengan uji Shapiro-Wilk karena nilai $n<3$ (Razali \& Wah, 2011). Hasil uji normalitas yang diperoleh disajikan di Tabel 3.

Tabel 3. Hasil uji normalitas data peningkatan kemampuan berpikir refraktif matematis

\begin{tabular}{ccccc}
\hline \multirow{2}{*}{ KAM } & Pembelajaran & $\boldsymbol{n}$ & Shapiro-Wilk & Sig. \\
\hline \multirow{2}{*}{ Tinggi } & PAR & 6 & 0,985 & 0,973 \\
\cline { 2 - 5 } & PK & 7 & 0,837 & 0,094 \\
\hline \multirow{2}{*}{ Sedang } & PAR & 27 & 0,950 & 0,217 \\
\cline { 2 - 5 } & PK & 26 & 0,925 & 0,059 \\
\hline \multirow{2}{*}{ Total } & PAR & 35 & 0,964 & 0,296 \\
\cline { 2 - 5 } & PK & 38 & 0,905 & 0,003 \\
\hline
\end{tabular}


Nilai signifikansi uji normalitas di Tabel 3 lebih kecil dari 0,05 pada peningkatan KBRM di pembelajaran konvensional sehingga uji homogenitas data hanya dilakukan pada mahasiswa KAM tinggi dan sedang. Hasil uji homogenitas terdapat pada Tabel 4.

Tabel 4. Hasil uji homogenitas data peningkatan kemampuan berpikir refraktif matematis

\begin{tabular}{|c|c|c|c|c|c|}
\hline KAM & Pembelajaran & Levene & $d f_{1}$ & $d f_{2}$ & Sig. \\
\hline \multirow{2}{*}{ Tinggi } & PAR & \multirow{2}{*}{0,027} & \multirow{2}{*}{1} & \multirow{2}{*}{11} & \multirow{2}{*}{0,872} \\
\hline & PK & & & & \\
\hline \multirow{2}{*}{ Sedang } & PAR & \multirow{2}{*}{11,353} & \multirow{2}{*}{1} & \multirow{2}{*}{51} & \multirow{2}{*}{0,001} \\
\hline & PK & & & & \\
\hline
\end{tabular}

Berdasarkan Tabel 4, variansi data peningkatan KBRM adalah homogen untuk mahasiswa KAM tinggi karena nilai signifikansi lebih besar dari 0,05. Selanjutnya, dilakukan uji perbedaan rerata menggunakan 3 jenis pengujian yang berbeda sesuai hasil normalitas dan homogenitas data, yakni uji- $t$, uji- $t^{\prime}$ dan uji Mann-Whitney U. Perolehan uji perbedaan rerata dapat dilihat dalam Tabel 5 .

Tabel 5. Hasil uji perbedaan rerata data peningkatan kemampuan berpikir refraktif matematis

\begin{tabular}{|c|c|c|c|c|c|}
\hline KAM & Pembelajaran & $t$ & $\boldsymbol{t}^{\prime}$ & Mann-Whitney U & Sig.(1-tailed) \\
\hline \multirow{2}{*}{ Tinggi } & PAR & \multirow{2}{*}{3,819} & & & \multirow{2}{*}{0,0015} \\
\hline & PK & & & & \\
\hline \multirow{2}{*}{ Sedang } & PAR & & \multirow{2}{*}{3,600} & & \multirow{2}{*}{0,0005} \\
\hline & PK & & & & \\
\hline \multirow{2}{*}{ Rendah } & PAR & & & \multirow{2}{*}{0,000} & \multirow{2}{*}{0,0265} \\
\hline & $\mathrm{PK}$ & & & & \\
\hline \multirow{2}{*}{ Total } & PAR & & & \multirow{2}{*}{248,000} & \multirow{2}{*}{0,000} \\
\hline & PK & & & & \\
\hline
\end{tabular}

Hasil uji perbedaan rerata di Tabel 5 memberikan informasi bahwa nilai signifikansi untuk secara keseluruhan lebih kecil dari 0,05 sehingga peningkatan KBRM mahasiswa kelompok pembelajaran PAR lebih baik dibandingkan peningkatan KBRM mahasiswa kelompok PK. Nilai signifikansi peningkatan KBRM mahasiswa KAM tinggi, sedang dan rendah pada kedua kelompok pembelajaran juga lebih kecil dari 0,05. Artinya, peningkatan KBRM mahasiswa yang memperoleh pembelajaran PAR lebih baik daripada mahasiswa yang memperoleh pembelajaran konvensional untuk semua kemampuan awal matematisnya.

\section{Pengaruh Interaksi antara Pembelajaran dan Kemampuan Awal Matematis terhadap Peningkatan Kemampuan Berpikir Refraktif Matematis}

Untuk menguji pengaruh interaksi antara faktor pembelajaran dan faktor KAM terhadap peningkatan KBRM mahasiswa, data mentah peningkatan KBRM perlu diubah dengan menggunakan Aligned Rank Transform (Higgins, Blair, \& Tashtoush, 1990) karena data 
mahasiswa KAM rendah tidak berdistribusi normal. Dengan bantuan software ARTool, data mentah peningkatan KBRM diubah menjadi data ART. Setelah itu, data ART peningkatan KBRM tersebut diolah menggunakan ANOVA dua arah berbantuan SPSS (Higgins, Blair \& Tashtoush, 1990) untuk mengetahui pengaruh interaksi kedua faktor. Output pengujian ANOVA dua arah disajikan di Tabel 6.

Tabel 6. Hasil uji ANOVA dua arah pengaruh jenis pembelajaran dan level KAM terhadap peningkatan kemampuan berpikir refraktif matematis

\begin{tabular}{lcrrrr}
\hline \multicolumn{1}{c}{ Source } & $\begin{array}{c}\text { Type III Sum } \\
\text { of Squares }\end{array}$ & $\boldsymbol{d}$ df & \multicolumn{1}{c}{$\begin{array}{c}\text { Mean } \\
\text { Square }\end{array}$} & \multicolumn{1}{c}{$\boldsymbol{F}$} & \multicolumn{1}{c}{ Sig. } \\
\hline Corrected Model & $11526,338^{\mathrm{a}}$ & 5 & 2305,268 & 7,417 & 0,000 \\
\hline Intercept & 48394,750 & 1 & 48394,750 & 155,710 & 0,000 \\
\hline Pembelajaran & 6428,583 & 1 & 6428,583 & 20,684 & 0,000 \\
\hline KAM & 1160,206 & 2 & 580,103 & 1,866 & 0,163 \\
\hline Pembelajaran * KAM & 846,920 & 2 & 423,460 & 1,362 & 0,263 \\
\hline Error & 20823,662 & 67 & 310,801 & & \\
\hline Total & 132287,000 & 73 & & & \\
\hline Corrected Total & 32350,000 & 72 & & & \\
\hline a. $R$ Squared $=0,356$ (Adjusted R Squared $=0,308)$ \\
\hline
\end{tabular}

Nilai Sig. dari Corrected Model yang terdapat dalam Tabel 6 adalah 0,000. Artinya, pengaruh faktor pembelajaran, faktor KAM dan interaksi pembelajaran dengan KAM, secara simultan terhadap peningkatan KBRM adalah signifikan. Faktor pembelajaran dan faktor KAM secara bersama-sama berkontribusi terhadap peningkatan KBRM sebesar 35,6\%, sisanya dipengaruhi oleh faktor lain.

Nilai Sig. untuk faktor pembelajaran dalam Tabel 6 lebih kecil dari 0,05. Artinya, peningkatan KBRM dipengaruhi oleh pembelajaran. Sementara itu, KAM tidak berpengaruh terhadap peningkatan KBRM. Dengan demikian, secara parsial, faktor pembelajaran lebih berpengaruh dibandingkan faktor KAM untuk meningkatkan KBRM mahasiswa.

Informasi lain dari Tabel 6 adalah tidak terdapat pengaruh yang signifikan pada peningkatan KBRM mahasiswa sebagai akibat interaksi faktor pembelajaran dan KAM. Dengan kata lain, interaksi antara pembelajaran dan KAM tidak berpengaruh terhadap peningkatan KBRM mahasiswa.

\section{Pembahasan}

Kemampuan berpikir refraktif matematis meningkat setelah diberikan perlakuan pembelajaran PAR. Hasil yang sama juga ditemukan oleh Angraini \& Wahyuni (2021) dan Retnaningsih \& Sugandi (2018) pada kemampuan berpikir kritis matematis melalui penerapan Concept Attainment Model dan Problem Based Learning. Kedua penelitian ini menunjukkan 
bahwa pembelajaran berpusat pada peserta didik dapat meningkatkan kemampuan berpikir kritis matematis. Meskipun berbeda pada jenis pembelajaran dan kemampuan berpikir tingkat tinggi yang diteliti, hal ini mengindikasikan bahwa berpikir kritis yang merupakan bagian dari berpikir refraktif (Pagano \& Roselle, 2009) dapat ditingkatkan oleh pembelajaran berpusat pada peserta didik.

Walaupun belum ditemukan penelitian mengenai penerapan model pembelajaran untuk meningkatkan KBRM pada mahasiswa KAM tinggi, sedang maupun rendah, ada dua penelitian yang mencirikan KBRM. Hasil kedua penelitian tersebut relevan dengan hasil penelitian ini. Pertama, penelitian Angraini dan Wahyuni (2021) dengan hasil penelitiannya antara lain peningkatan kemampuan berpikir kritis matematis mahasiswa pada Concept Attainment Model lebih tinggi daripada pembelajaran konvensional untuk setiap level KAM. Kedua, penelitian Nindiasari, Kusumah, Sumarmo, \& Sabandar (2014) mengenai pendekatan metakognitif untuk meningkatkan kemampuan berpikir reflektif matematis siswa SMA. Salah satu hasil dari penelitian Nindiasari, Kusumah, Sumarmo, dan Sabandar (2014) yaitu peningkatan kemampuan berpikir reflektif matematis siswa pada pendekatan metakognitif lebih baik dibandingkan dengan pembelajaran konvensional ditinjau dari KAM. Kedua penelitian tersebut memberikan hasil bahwa kemampuan berpikir kritis matematis dan kemampuan berpikir reflektif matematis meningkat untuk tiap level KAM setelah diberikan pembelajaran berpusat pada peserta didik.

Pada penelitian ini, peningkatan KBRM masih belum memuaskan pada kedua kelompok penelitian. Peningkatan KBRM banyak terjadi pada mahasiswa KAM tinggi dalam pembelajaran PAR. Hasil yang sama juga ditemukan oleh Angraini \& Wahyuni (2021) pada kemampuan berpikir kritis matematis mahasiswa. Peningkatan kemampuan berpikir kritis matematis mahasiswa KAM tinggi lebih baik daripada mahasiswa KAM sedang dan rendah setelah diterapkan Concept Attainment Model.

Pada pembelajaran PAR, setiap mahasiswa harus terlibat dalam semua kegiatan pembelajaran. Mahasiswa belajar dengan rekan sejawat (lihat Gambar 3). Pada tiap kelompok terdapat seorang mahasiswa tutor. Tutor berfungsi sebagai model bagi tutee yang memiliki tugas menjelaskan dan mendemonstrasikan keterampilan, operasi, dan strategi yang harus dipelajari oleh tutee (Schunk, 2012). 


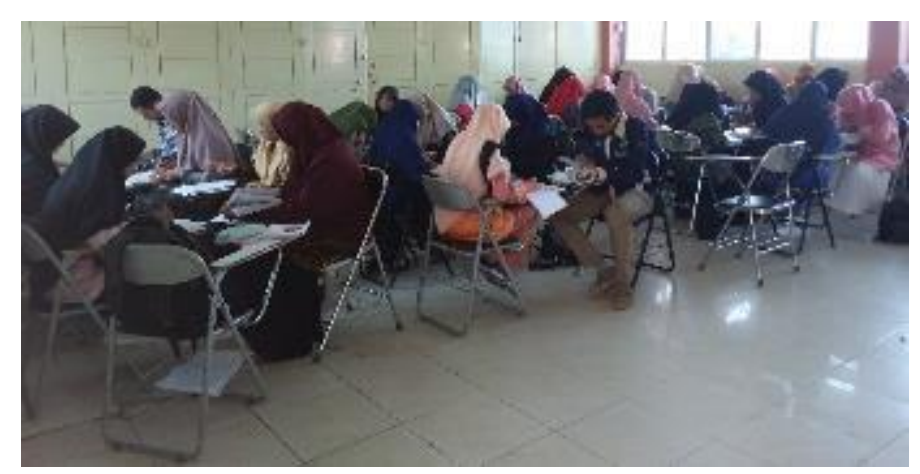

Gambar 3. Mahasiswa belajar dengan rekan sejawat dalam pembelajaran PAR

Pada pembelajaran PAR, mahasiswa KAM tinggi yang berperan sebagai tutor harus memiliki kemampuan atau pengalaman agar mahasiswa KAM rendah yang berperan sebagai tutee mampu memahami konsep dan menyelesaikan masalah di lembar tugas. Yaman (2017) menyatakan mahasiswa yang memiliki kemampuan atau pengalaman lebih banyak membantu mahasiswa yang kemampuannya kurang. Kegiatan seperti ini biasanya terjadi pada saat umpan balik, mahasiswa KAM tinggi memberikan penjelasan pada mahasiswa KAM rendah (Gambar 4).

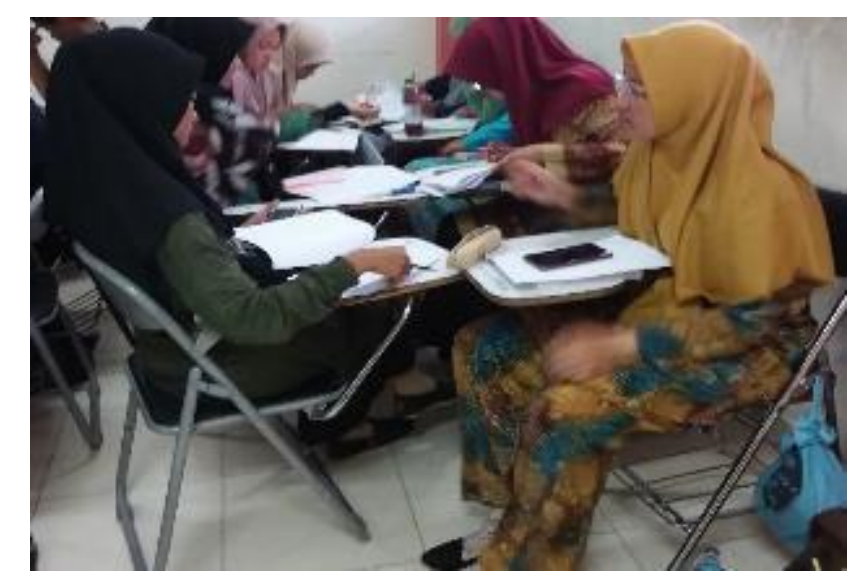

Gambar 4. Kegiatan umpan balik pada pembelajaran PAR

Interaksi lain yang terjadi dalam pembelajaran PAR adalah setiap mahasiswa mengomentari hasil kerja rekan sejawat (peer assessment). Mahasiswa KAM rendah juga melakukan kegiatan ini pada mahasiswa KAM tinggi. Meskipun komentar yang diberikan 'kurang berarti' bagi mahasiswa KAM tinggi, karena dilakukan secara berulang, mahasiswa tersebut berusaha untuk tidak melakukan hal yang sama pada hasil kerjanya sendiri (Black, Harrison, Lee, Marshall, \& Wiliam, 2003). Interaksi yang terjadi dalam peer assessment dapat menghasilkan kemampuan berkolaborasi, berkomunikasi, pemahaman konseptual dan pemecahan masalah (Nicol, Thomson, \& Breslin, 2013; Reinholz, 2017). 
Dengan adanya interaksi pembelajaran sebagaimana telah dijelaskan di atas, mengakibatkan pemahaman tiap mahasiswa semakin meningkat. Mahasiswa dituntun aktif dalam berpikir dan bertindak selama proses pembelajaran. Akhirnya, kemampuan berpikir refraktif matematis mahasiswa semakin membaik.

Hasil penelitian tentang pengaruh interaksi faktor pembelajaran dan level KAM pada peningkatan KBRM adalah tidak signifikan. Hasil penelitian yang sama juga diperoleh oleh Widyatiningtyas, Kusumah, Sumarmo, dan Sabandar (2015), Jumaisyaroh, Napitupulu, dan Hasratuddin (2014), dan Yumiati \& Kusumah (2019) bahwa tidak ada pengaruh interaksi antara pendekatan pembelajaran dan KAM terhadap kemampuan berpikir kritis matematis. Selain pada kemampuan berpikir kritis matematis, Nindiasari, Kusumah, Sumarmo, dan Sabandar (2014) menemukan bahwa tidak ada pengaruh interaksi antara pembelajaran (metakognitif dan biasa) dengan KAM terhadap kemampuan berpikir reflektif matematis. Dengan demikian, peningkatan kemampuan berpikir kritis matematis dan kemampuan berpikir reflektif matematis (merupakan bagian dari berpikir refraktif) tidak dipengaruhi oleh interaksi antara jenis pembelajaran dan KAM.

Hasrida (dalam Nika, Wiryokusumo, \& Karyono, 2019) mengungkapkan bahwa pembelajaran dan kemampuan awal tidak saling mempengaruhi. Hal ini terjadi akibat perbedaan cara belajar. Nika, Wiryokusumo, \& Karyono (2019) berpendapat bahwa siswa KAM tinggi lebih cenderung untuk mandiri dalam belajar, sedangkan siswa KAM rendah lebih senang menunggu hasil kerja temannya.

Apabila dilihat hasil lembar tugas mahasiswa pada pembelajaran PAR, mahasiswa KAM tinggi lebih banyak menjawab pertanyaan dibandingkan mahasiswa KAM rendah. Lembar tugas mahasiswa KAM rendah lebih banyak terisi di bagian revisi, setelah ada komentar dari pasangannya yang berkemampuan tinggi.

\section{Simpulan}

Peningkatan kemampuan berpikir refraktif matematis ditinjau dari semua level kemampuan awal matematis mahasiswa pada pembelajaran PAR lebih baik dibandingkan pembelajaran konvensional. Peningkatan kemampuan berpikir refraktif matematis paling banyak terjadi pada mahasiswa kemampuan awal matematis tinggi. Interaksi pembelajaran (PAR dan konvensional) dengan KAM (tinggi, sedang, rendah) tidak berpengaruh secara signifikan terhadap peningkatan kemampuan berpikir refraktif matematis. Faktor yang paling mempengaruhi peningkatan kemampuan berpikir refraktif matematis adalah pembelajaran. 


\section{Referensi}

Angraini, L. M., \& Wahyuni, A. (2021). The effect of concept attainment model on mathematical critical thinking ability. International Journal of Instruction, 14(1), 727742. https://doi.org/10.29333/iji.2021.14144a.

Black, P., Harrison, C., Lee, C., Marshall, B., \& Wiliam, D. (2003). Assessment for learning: Putting it into Practice. Maidenhead: Open University Press.

Calkins, S., Grannan, S., \& Siefken, J. (2020). Using peer-assisted reflection in math to foster critical thinking and communication skills. PRIMUS, 30(4), 475-499. https://doi.org/10.1080/10511970.2019.1608608.

Fatmalasari, D. A., \& Siswono, T. Y. E. (2020). Refractive thinking of visualizer and verbalizer students in solving geometry problems. Jurnal Ilmiah Pendidikan Matematika Volume, 9(2). 356-362. https://doi.org/10.26740/mathedunesa.v9n2.p356-362.

Ghasemi, A., \& Zahediasl, S. (2012). Normality tests for statistical analysis: A guide for nonstatisticians. International Journal of Endocrinology and Metabolism, 10(2), 486-489. https://doi.org/10.5812/ijem.3505.

Hake, R. R. (1998). Interactive-engagement versus traditional methods: A six-thousand-student survey of mechanics test data for introductory physics courses. American Journal of Physics, 66(1), 64-74. https://doi.org/10.1119/1.18809.

Higgins, J. J., Blair, R. C., \& Tashtoush, S. (1990). The aligned rank transform procedure. In Proceedings of Annual Conference on Applied Statistics in Agriculture (hlm. 185-195). Kansas: New Prairie Press. https://doi.org/10.4148/2475-7772.1443.

Jumaisyaroh, T., Napitupulu, E. E., \& Hasratuddin, H. (2015). Peningkatan kemampuan berpikir kritis matematis dan kemandirian belajar siswa SMP melalui pembelajaran berbasis masalah. Kreano, Jurnal Matematika Kreatif-Inovatif, 5(2), 157-169. https://doi.org/10.15294/kreano.v5i2.3325.

Maslukha, M., Lukito, A., \& Ekawati, R. (2018). Refractive thinking profile in solving mathematical problem reviewed from students math capability. Journal of Physics: Conference Series, 947(1), 012022. https://doi.org/10.1088/1742-6596/947/1/012022.

Meltzer, D. E. (2002). The relationship between mathematics preparation and conceptual learning gains in physics: A possible "hidden variable" in diagnostic pretest scores. American Journal of Physics, 70(12), 1259-1268. https://doi.org/10.1119/1.1514215.

Nicol, D., Thomson, A., \& Breslin, C. (2013). Rethinking feedback practices in higher education: A peer review perspective. Assessment \& Evaluation in Higher Education, 39(1), 102-122. https://doi.org/10.1080/02602938.2013.795518.

Nika, K., Wiryokusumo, I., \& Karyono, H. (2019). Pengaruh penggunaan model kooperatif tipe numbered head together dan direct instruction terhadap hasil belajar matematika pokok bahasan aritmatika sosial ditinjau dari kemampuan awal. Jurnal Education and Development, 7(3), 42-42.

Nindiasari, H., Kusumah, Y. S., Sumarmo, U., \& Sabandar, J. (2014). Pendekatan metakognitif untuk meningkatkan kemampuan berpikir reflektif matematis siswa SMA. Edusentris, 1(1), 80-90. https://doi.org/10.17509/edusentris.v1i1.136.

Pagano, M. \& Roselle, L. (2009). Beyond reflection: Refraction and international experiential learning. Frontiers: The Interdisciplinary Journal of Study Abroad, 18, 217-229. https://doi.org/10.36366/frontiers.v18i1.263.

Prayitno, A., Sutawidjaja, A., Subanji \& Muksar, M. (2014b). Proses berpikir refraksi siswa menyelesaikan masalah data "membuat keputusan". Dalam Prosiding Seminar Nasional TEQIP (Teachers Quality Improvement Program) dengan tema "Membangun Karakter Bangsa melalui Pembelajaran Bermakna TEQIP (hlm. 154-162). Malang: Universitas Negeri Malang. 
Prayitno, A., Subanji \& Muksar, M. (2016). Refractive thinking with dual strategy in solving mathematics problem. IOSR Journal of Research \& Method in Education (IOSR-JRME), 6(3), 49-56.

Prihati, C. N., \& Wijayanti, P. (2017). Profil berpikir refraktif siswa SMP dalam memecahkan masalah geometri ditinjau dari tipe kepribadian Keirsey. Mathedunesa: Jurnal Ilmiah Pendidikan Matematika, 1(6), 48-57. https://doi.org/10.30998/formatif.v6i1.753.

Razali, N. M., \& Wah, Y. B. (2011). Power comparisons of Shapiro-Wilk, KolmogorovSmirnov, Lilliefors and Anderson-Darling Tests. Journal of Statistical Modeling and Analytics, 2(1), 21-33.

Reinholz, D. L. (2015). Peer-assisted reflection: A design-based intervention for improving success in calculus. International Journal of Research in Undergraduate Mathematics Education, 1(2), 234-267. https://doi.org/10.1007/s40753-015-0005-y.

Reinholz, D. (2016). The assessment cycle: A model for learning through peer assessment. Assessment \& Evaluation in Higher Education, 41(2), 301-315. https://doi.org/10.1080/02602938.2015.1008982.

Reinholz, D. (2017). Peer conferences in calculus: The impact of systematic training. Assessment \& Evaluation in Higher Education, 42(1), 1-17. https://doi.org/10.1080/02602938.2015.1077197.

Reinholz, D. L., \& Dounas-Frazer, D. R. (2016). Using peer feedback to promote reflection on open-ended problems. The Physics Teacher, 54(6), 364-368. https://doi.org/10.1119/1.4961181.

Retnaningsih, M., \& Sugandi, A. I. (2018). The role of problem based learning on improving students' mathematical critical thinking ability and self-regulated learning. (JIML) Journal of Innovative Mathematics Learning, 1(1), 8-17. https://doi.org/10.22460/jiml.v1i2.p60-69.

Schunk, D. H. (2012). Learning theories: An educational perseptive. Sixth Edition. Boston: Pearson.

Widyatiningtyas, R., Kusumah, Y. S., Sumarmo, U., \& Sabandar, J. (2015). The impact of problem-based learning approach to senior high school students' mathematics critical thinking ability. Journal on Mathematics Education, 6(2), 30-38. https://doi.org/10.22342/jme.6.2.2165.107-116.

Yaman, B. B. (2019). A multiple case study: What happens in peer tutoring of calculus studies? International Journal of Education in Mathematics, Science and Technology, 7(1), 53-72. https://doi.org/10.18404/ijemst.328336.

Yumiati, Y., \& Kusumah, Y. (2019). Interaction between students' learning and early mathematical skills to increase mathematical critical thinking skills. Al-Jabar Jurnal Pendidikan Matematika, 10(1), 125-134. https://doi.org/10.24042/ajpm.v10i1.3712. 